\title{
Description of the Learning Difficulties on Chapter Parabolic Motion and the Factors Affecting in Physics Pre-Service Teacher
}

\author{
Yunita Arifatul Wanda ${ }^{1}$, Indah Slamet Budiarti ${ }^{*}$, Florentina Maria Panda ${ }^{\mathbf{1}}$ \\ ${ }^{1}$ Physics Education Department, Universitas Cenderawasih, Kamp Wolker, Kambolker Street \\ Perumnas III, Yabansai, Heram, Jayapura City, Papua, Indonesia 99224 \\ *Correspondence: indah_budiarti@yahoo.com
}

\begin{tabular}{ll}
\hline Abstract \\
\hline Keywords: & The problem of student learning difficulties and the factors causing it are very \\
External Factors, & important to know. The first step that can be taken is to use a diagnostic test as a \\
Internal Factors, & reference indicator in identifying student learning difficulties. The purpose of this \\
Learning Difficulties, & study was to determine the difficulties in learning parabolic motion and its causal \\
Misconceptions, & factors experienced by students of the 2018 Physics Education Department. This type \\
Parabolic Motion & of research is descriptive. The subjects of this study were 19 students of the 2018 \\
& Cenderawasih University in the Physics Education Department. Data collection \\
& techniques used are test, interview, and documentation. The results of the overall \\
& assessment of the diagnostic test showed that 19 students had not yet completed \\
& achieving the learning objectives in understanding the parabolic motion sub-material \\
because the highest score obtained by one of the students was 53, while the minimum \\
completeness reached a score of 56. These difficulties are influenced by internal \\
factors, namely body defects, fatigue, attention, readiness, habits, how to receive \\
lessons, boredom; and external factors, namely the lecturer's teaching methods, \\
discipline, building conditions, forms of community life, and weather conditions.
\end{tabular}

To cite this article:

Wanda, Y.A., Budiarti, I.S., Panda, F.M. (2021). Description of the Learning Difficulties on Chapter Parabolic Motion and the Factors Affecting in Physics Pre-Service Teacher. Thabiea : Journal of Natural Science Teaching, 4(2), 170-184.

\section{Introduction}

There is a fundamental goal of raising the nation's educational outcomes year by year. Education is one of the important things in human life, where education will guarantee a better life for humans themselves (Kurniawan, Perdana, \& Kurniasari, 2018). Education is an activity to optimize the development of the potential, skills, and characteristics of students (Wardani, 2016). Learning in higher education requires students to master the material provided by the lecturer during the implementation of learning (Pertiwi, 2012). The indicator of student success in mastering the material is an increase in the quality of learning outcomes (Nugraheni, 2017). The quality of learning outcomes is very important for the development of student learning, especially for students majoring in education who are later expected to distribute the knowledge gained to students (Gong et al., 2021). The outcomes are intended to be a basic reflection on how education in certain nations is elaborated.

Physics Education Department students need a high conceptual understanding of Basic Physics materials to achieve maximum learning outcomes (Kusumah, 2019). In the future, it is expected to become a Physics Teacher who has pedagogic competence (Kaltakci-Gurel et al., 2017). Students still have learning outcomes that have not been maximized, which is proof 
that there are still some students who get a score of 60 (maximum scale of 100) (Theasy et al., 2017). Students are said to have learning difficulties marked by the acquisition of learning outcomes that are not optimal (Karim \& Saepuzaman, 2016b), so that lecturers have a responsibility in optimizing the learning process during lectures (Binkley et al., 2012).

There are several problems in learning physics, including a lack of interest in basic physics courses because physics is considered difficult for most students; the low average score for the final semester exam is 6.5; students get bored easily and forget because the teaching system still emphasizes rote memorization; students tend to depend on other friends in doing assignments; and students' difficulties in understanding the concepts presented by the lecturer (Griffin et al., 2012). The ability of each student in understanding the learning material is different. However, these problems prove that most students still have learning difficulties and need a relatively long time to understand learning (Hesse et al., 2015).

Learning difficulties are a condition where students cannot learn optimally due to obstacles, obstacles, or disturbances in their learning (Darimi, 2016). In addition, learning difficulties indicate that there is a gap between the expected achievements and the achievements obtained (Ngang et al., 2014). This can lead to a situation where students cannot learn properly so that which has an impact on low learning achievement (Jamal, 2019). Thus, learning difficulties are a condition where students experience problems in obtaining and absorbing the learning provided (Cheng \& Hoe, 2017; Cheng et al., 2017).

Factors that cause students to experience learning difficulties, including internal factors are factors that come from within students, including factors of interest, attention, motivation, and study habits; and external factors are factors that come from outside the student, including teaching methods, learning media, and learning resources (Nofitasari \& Sihombing, 2017). The low mastery of concepts, weak mathematical abilities, and the inability of students to convert units, as well as the low ability to translate question language into mathematical language, are the causes of students' difficulties in understanding physics learning (Briliana \& Mursito, 2017; Lee, 2016; Trisniarti et al., 2020).

One of the basic physics materials that are considered difficult or often experiences misconceptions is parabolic motion (Yolanda, 2017). Parabolic motion material is one of the topics in 2-dimensional kinematics material, which is a branch of classical mechanics that discusses the motion of objects and object systems without questioning the forces that cause motion (Sarojo, 2002). In parabolic motion concepts, students experience errors in answering questions by $54 \%$ because they only focus on memorizing the formula for the time taken during the half parabolic trajectory, maximum height, maximum farthest distance, and it is difficult to apply it in situations or trajectories the new one (Lei et al., 2020). Another study states that students have difficulty in determining velocity and acceleration vectors in parabolic motion (Nisa, F., Yuliati, L., \& Mufti, 2019).

Students find it difficult to understand why the velocity on the y-axis at the top of the parabola is zero, while the acceleration is not zero (Haris, 2016). In addition, many students think that if the object is at the top of the parabola, then the object is stationary or has no speed for a certain time, when in fact the object is still moving horizontally (Rosdianto, 2019). These studies prove that there are still many difficulties and even misconceptions experienced by students in the parabolic motion material. Based on a preliminary study through interviews with one of the lecturers in the basic physics course I Physics Education Department, 
Cenderawasih University, the lecturer explained that the average learning outcomes for basic physics I were still below 70. It is caused by a lack of understanding of basic and mathematical concepts in understanding the quantities of parabolic motion (Kareth et al., 2018).

The problem of student learning difficulties must be addressed immediately, with the first step that can be taken is to identify student learning difficulties, so that efforts can be made to reduce and even overcome these learning difficulties (Salis et al., 2016). Thus, this study uses a diagnostic test effort as a reference indicator in identifying student learning difficulties (Biben et al., 2016). The Ministry of National Education explains that a diagnostic test is a test used to find out the weaknesses of students so that these results can be used as the basis for follow-up in the form of appropriate treatment and accordance with these weaknesses (Setyono et al., 2016). There are five approaches in the diagnostic test, namely the approach to learning objectives, material profiles, knowledge prerequisites, misconceptions, and structured knowledge (Rusilowati, 2015).

Based on the problems that have been stated above, the researcher aimed to describe student learning difficulties using diagnostic tests and interviewing students to find out the factors that cause learning difficulties faced. The advantage of this diagnostic test is that it can identify student learning problems or difficulties, and plan efforts to solve the problems faced. Thus, this study aims to determine the percentage of learning difficulties and the factors that influence student learning difficulties on the concept of parabolic motion, so that educators can plan further actions appropriately in learning.

\section{Method}

The research method used is a descriptive method that serves to provide an overview or describe the object under study through sample or population data as it is, without analyzing and making conclusions that apply to the public (Sugiyono, 2013). This study was to describe how much difficulty students experience in understanding the concept of parabolic motion material and the causal factors that influence it.

Data collection techniques were using a test, interview, and documentation. The test instrument used was a diagnostic test to determine the profile of students' difficulties in the parabolic motion material. The interview instrument used is a guided interview, wherein this study students will be asked questions about the factors that influence their learning difficulties in physics. Documentation was done through a pilot study where students were examined to have difficulties in physics during the course.

The data analysis technique used in this research was to answer the diagnostic test results based on the approach to learning objectives, material profiles, knowledge prerequisites, misconceptions, and structured knowledge. Analysis based on learning objectives and material profile was using the percentage of student scores formulated by equation in Figure 1.

$$
\% \text { score }=\frac{\text { score of students with learning difficulties }}{\text { maximum score }} \times 100 \%
$$

Figure 1. Equation of the Percentage of Student Scores 
Difficulty category provisions are made based on the achievement of goals. The learning objectives experienced completeness at a percentage of $65 \%$. Students are said to have difficulty if: $\%$ score $35 \%=$ strong category and $\%$ score $>35 \%=$ weak category. Difficulty analysis based on prerequisite knowledge, misconceptions, and structured knowledge uses the same formula and frequency but does not use scores. The provisions for the category of student learning difficulties are listed in Table 1.

Table 1. Criteria of Learning Difficulties

\begin{tabular}{cc}
\hline Percentage Score & Criteria \\
\hline $0 \%-39 \%$ & Low \\
$40 \%-65 \%$ & Moderate \\
$66 \%-79 \%$ & High \\
$80 \%-100 \%$ & Very High \\
\hline
\end{tabular}

(Sudijono, 2010)

\section{Results and Discussion}

\section{Learning Objectives}

\section{Student's Difficulty Profile on Parabolic Motion Concepts}

The completeness of learning objectives based on the academic assessment of Cenderawasih University is to get a minimum score of 56. The results of the study of learning difficulties based on the achievement of learning objectives are illustrated in Figure 2.

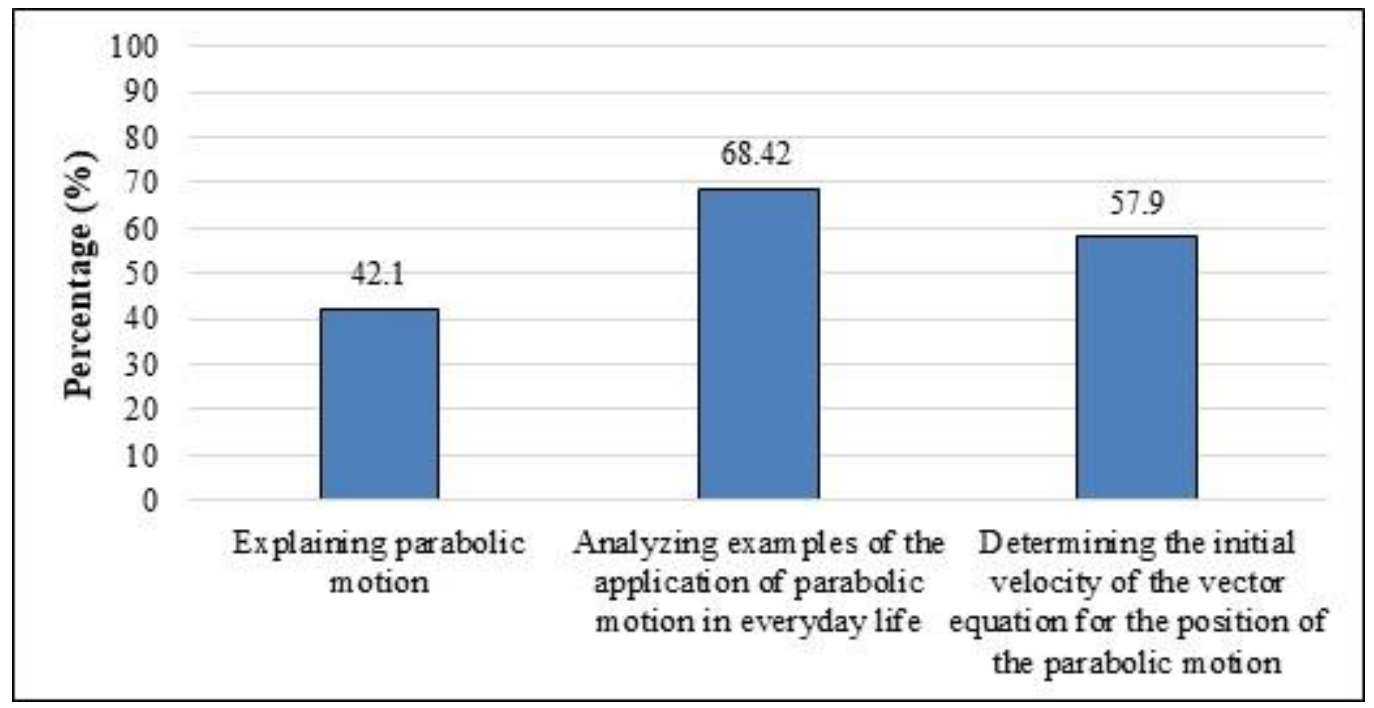

Figure 2. Profile of Learning Difficulties Based on Learning Objectives

The diagnostic test indicators in this profile are: 1) Explaining parabolic motion, 2) Analyzing examples of the application of parabolic motion in everyday life, and 3) Determining the initial velocity of the vector equation for the position of the parabolic motion. Based on the results of the overall assessment of the diagnostic test that 19 students have not completed achieving the learning objectives because the highest score obtained by one of the students is 53 , while the minimum completeness reaches a value of 56 . Figure 2 shows three indicators of questions included in the approach to learning objectives, it can be 
seen that the level of difficulty of students on the indicator of analyzing examples of the application of parabolic motion in daily life has the highest percentage, namely $68.42 \%$. The lowest level of difficulty is the indicator explaining the meaning of parabolic motion, which is worth $42.1 \%$. This can be seen from the results of student work, where students cannot determine examples of the application of parabolic motion and determine the initial speed of parabolic motion correctly. This is in line with the opinion of Nisa et al. (2019), which states that students have difficulty in determining the velocity vector and acceleration of the parabolic motion. It can be said that students still have difficulty in achieving learning objectives related to analyzing the initial speed of parabolic motion.

\section{Profile of Parabolic Motion Concepts}

The material profile is a sub-material in a certain material scope, so the material profile approach is to find out the sub-materials that have or have not been mastered by students (Rusilowati, 2006; Rusilowati, 2015). The following is a profile of students' difficulties with the material profile shown in Figure 3.

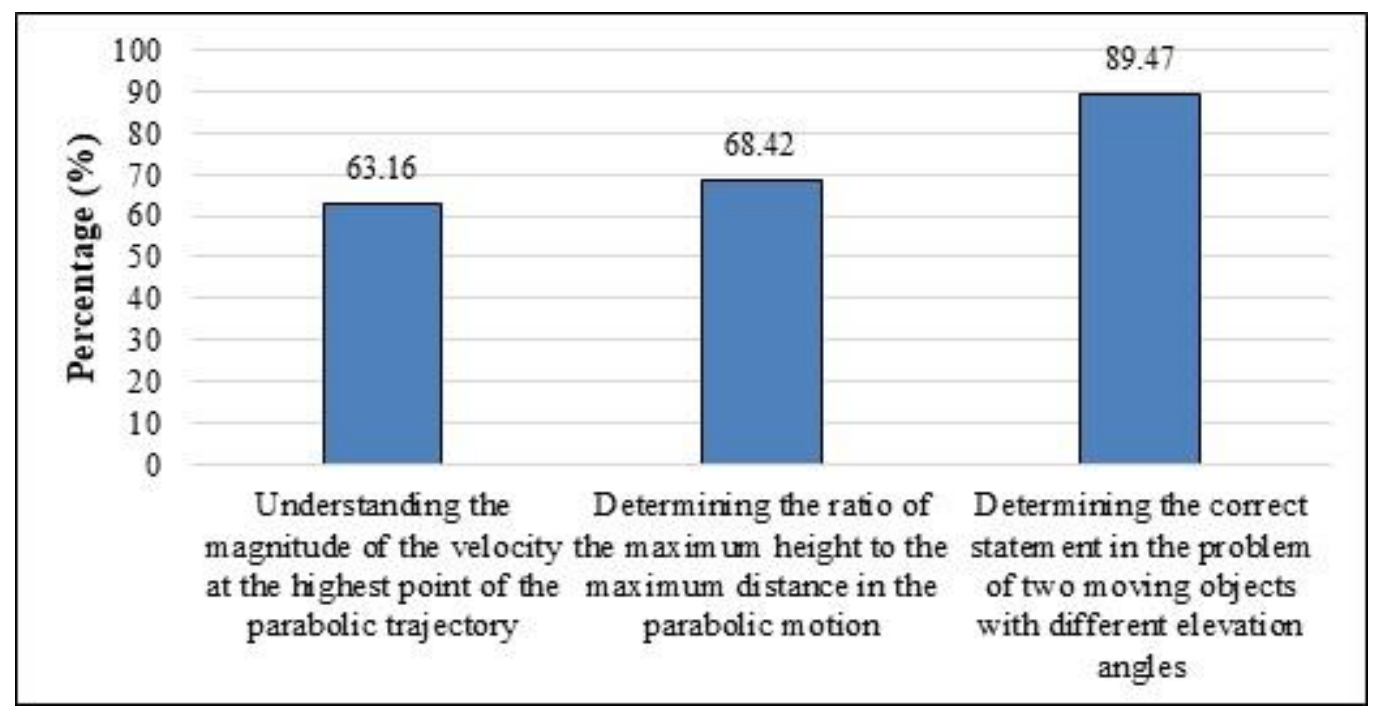

Figure 3. Learning Difficulty Profile Based on Material Profile

The diagnostic test indicators in this profile are: 1) Understanding the magnitude of the velocity at the highest point of the parabolic trajectory, 2) Determining the ratio of the maximum height to the maximum distance in the parabolic motion, and 3) Determining the correct statement in the problem of two moving objects with different elevation angles. According to Sudijono (2010), the data analysis of the material profile approach is the same as the learning objectives, so 19 students are not complete in understanding the sub-materials on the parabolic motion material because the highest score obtained by one of the students is 53, while the minimum completeness reaches a value of 56.2. It shows the three question indicators included in the material profile approach. It is seen that the level of student difficulty in determining the correct statement on the problem of 2 objects with different elevation angles has the highest percentage of $89.47 \%$. While the lowest level of difficulty is the indicator of understanding the speed of the highest point of parabolic motion, which is 63.16\%. parabolic motion is often included in difficult concepts (Lei et al., 2020). 
Students who were interviewed mentioned that they had difficulty in understanding the equations of motion of the parabola, namely the initial velocity, the highest point, the time to reach the highest point, and the maximum distance. In line with Wijayanti (2016), learning physics has several problems, one of which is that students easily forget because the teaching system emphasizes memorizing physics equations. Furthermore, students have difficulty in mastering the sub-chapter speed of the highest point of parabolic motion. This is because students have an understanding that an object that is thrown vertically upwards, the higher the object, the greater the speed. Other studies say that students find it difficult to understand why the velocity on the y-axis at the highest position is zero (Ma'rifah, 2016). When an object is moving higher, the speed will be smaller (Khandagale \& Chavan, 2017; Zatsiorsky \& Zaciorskij, 2002). When the object is at the peak / highest point, then the object will stop for a moment so that its speed will be equal to zero (Serway \& Jewett, 1998; Volfson et al., 2020).

\section{Prerequisite Knowledge}

Prerequisite knowledge is very important in problem-solving efforts. The profile of student difficulties based on mastery of prerequisite knowledge can be seen in Figure 4.

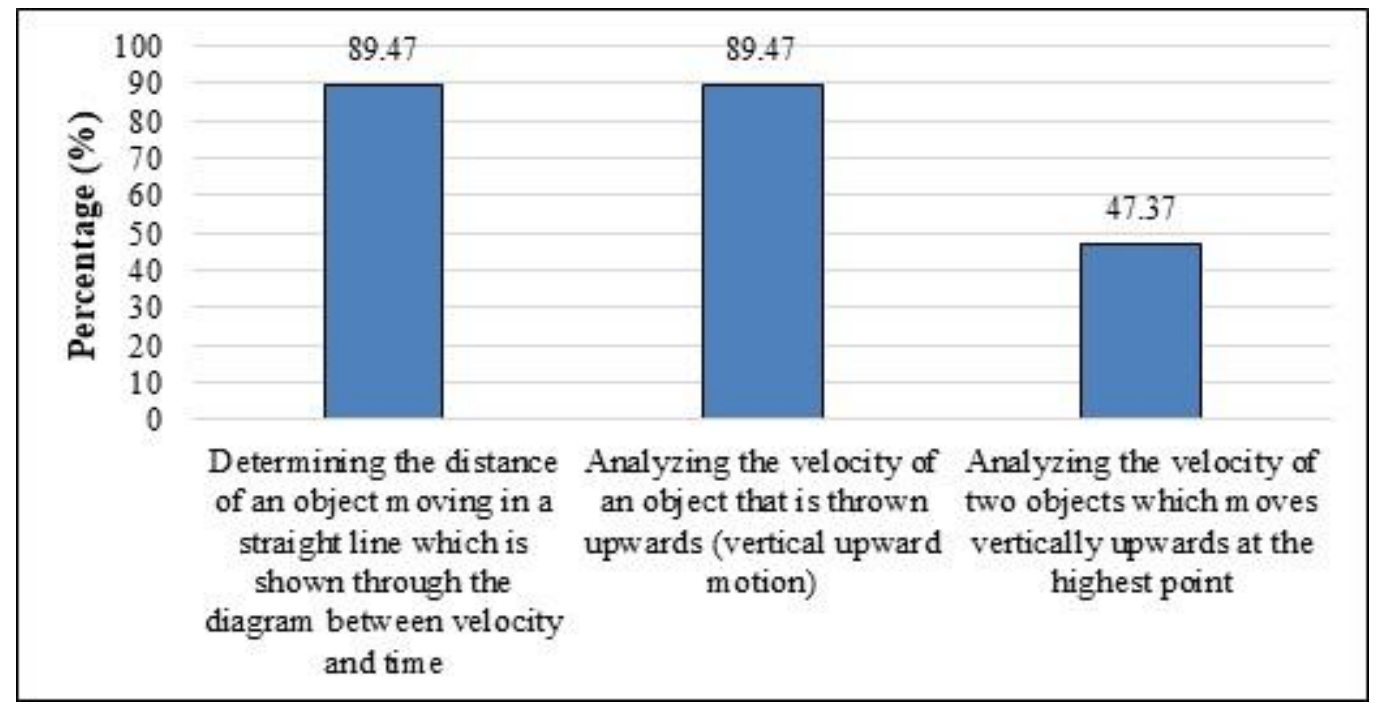

Figure 4. Learning Difficulty Profile Based on Prerequisite Knowledge

The diagnostic test indicators in this profile are: 1) Determining the distance of an object moving in a straight line which is shown through the diagram between velocity and time, 2) Analyzing the velocity of an object that is thrown upwards (vertical upward motion), and 3) Analyzing the velocity of two objects which moves vertically upwards at the highest point. Based on the results of the data analysis shown in Figure 4, the criteria for learning difficulties are varied. According to Sudijono (2010), it shows that the level of student difficulty in the indicator determines the distance of an object moving in a straight line which is displayed through a diagram between speed and time and analyzes the speed of an object that is thrown upwards or vertical motion up) is classified as very high at $89.47 \%$. While the level of difficulty that is classified as moderate is an indicator of analyzing the speed of two objects moving vertically upwards at the highest point, which is worth $47.37 \%$. 
Students have the most difficulty in mastering the difference between straight motion without acceleration and straight motion with acceleration used in determining the distance traveled from a graph of the relationship between speed and time. In line with the research of Handhika et al. (2015) which said that $92.06 \%$ of students had difficulties with graphs, even though students were able to write the equations and mention them verbally. In general, students also have difficulty in arithmetic operations or mathematical calculations (Lee, 2016; Rodriguez-Gil et al., 2016). Based on interviews conducted, students said that they had difficulty in calculating mathematically, even though they could remember the physics equations. One of the causes of students' learning difficulties is arithmetic operations or mathematical calculations, and also other causes are understanding concepts and converting units (Rusilowati, 2015).

In addition, students misunderstood the concept of vertical upward motion. Students said that when the highest point of an object moves vertically upwards, the velocity will be greater. The results of this study were also strengthened by the research of Ma'rifah (2016) which says that other studies say that students find it difficult to understand why the velocity on the y-axis at the highest position is zero. The majority of students who had learning difficulties in kinematics concepts (parabolic motion is included in kinematics concepts) hold the same points. They do not understand the mathematical equation to project the axis along the $\mathrm{x}$ and y-axis (Budiarti \& Tanta, 2021; Çelik et al., 2018; Winarti et al., 2017).

\section{Misconception}

For the last decade, the misconception is determined as one of the learning difficulties factors affecting (Milenković et al., 2016). A misconception often is in disguise as conceptual understanding without a concrete and empirical knowledge (Silva \& Almeida, 2017). The profile of student difficulties based on misconceptions can be seen in Figure 5.

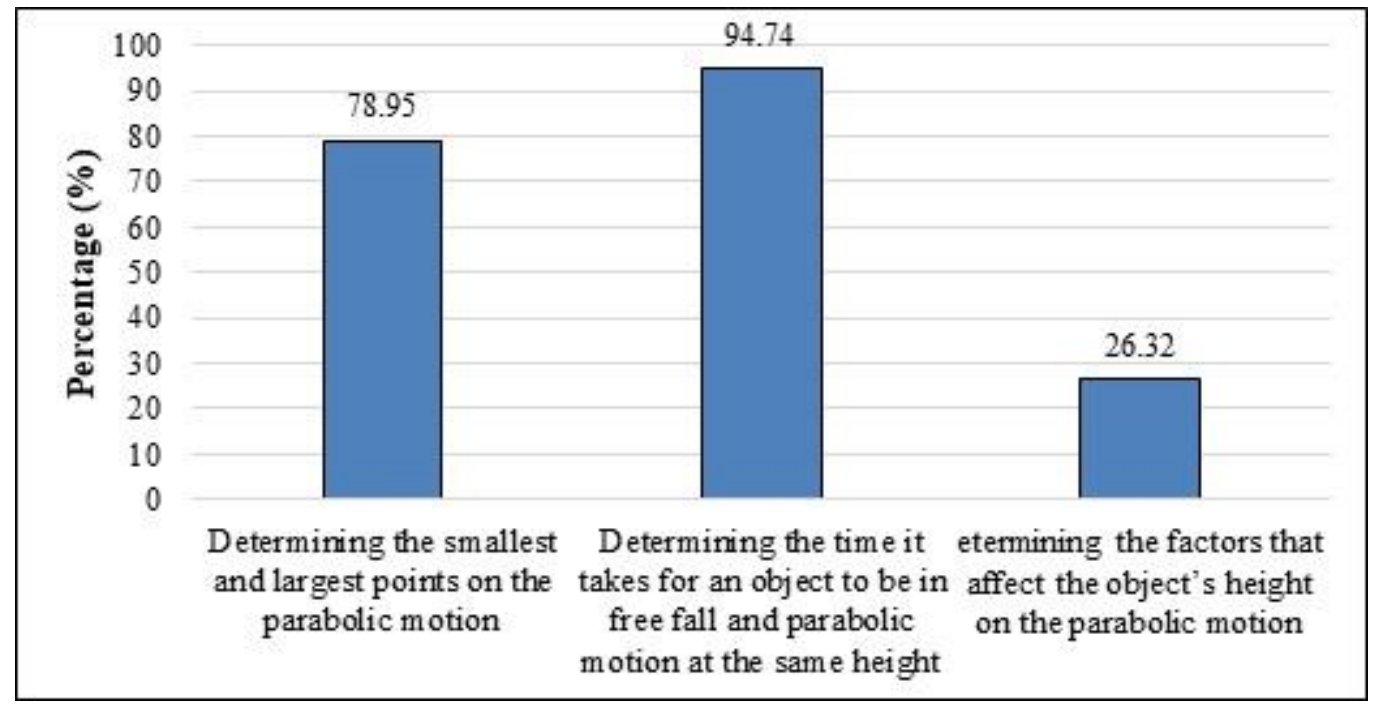

Figure 5. Learning Difficulty Profile Based on Misconception

The diagnostic test indicators in this profile are: 1) Determining the smallest and largest points on the parabolic motion, 2) Determining the time it takes for an object to be in free fall and parabolic motion at the same height, and 3) Determining the factors that affect 
the object's height on the parabolic motion. Based on the results of the data analysis shown in Figure 5, it shows that the level of student difficulty in the indicator determines the time it takes for objects with free-fall motion and parabolic motion at the same height, classified as very high, namely $94.74 \%$. The level of difficulty that is classified as high is an indicator of determining the smallest speed point and the largest parabolic motion, which is worth $78.95 \%$. While the level of difficulty is relatively low $(26.32 \%)$. That is, the indicator determines the factors that affect the height of the object in parabolic motion. The difficulty of students in the very high category is based on the misconception that students think that an object will reach the ground faster if it is freely dropped (free-fall motion) rather than shot (parabolic motion) (Serway \& Jewett, 1998). Based on the correct concept, objects that are freely dropped and fired at the same height will both reach the ground (Linh et al., 2019; Saripudin, 2018).

Misconceptions also occur that students assume that the greatest speed of parabolic motion is when it is at the peak/highest point and the lowest speed is when it reaches the farthest distance/point. The correct concept is that the smallest speed of parabolic motion is when it is at the peak/highest point based on the equation $v_{t}=v_{o}+a t$ and the greatest speed is when it reaches the farthest distance/point based on the equation $v_{t}^{2}=v_{o}^{2}-2 g h$ (Karim \& Saepuzaman, 2016a). Misconceptions in parabolic motion are often caused by the lack of a basic understanding of trigonometry in mathematics concepts (Herga et al., 2016; Ndihokubwayo et al., 2020). Meanwhile, it can be reduced by strengthening students' conceptual understanding of mathematical equations (Junaidi \& Lutfianto, 2018).

\section{Structured Knowledge}

Structured knowledge is the stages of problem-solving starting from understanding the problem, making plans, implementing plans, and checking again (Setyono et al., 2016). A structured knowledge approach is used to analyze students' inability to solve structured problems (Çakici \& Turkmen, 2013; Mukhopadhyay, 2014). The profile of student difficulties based on structured knowledge can be seen in Figure 6.

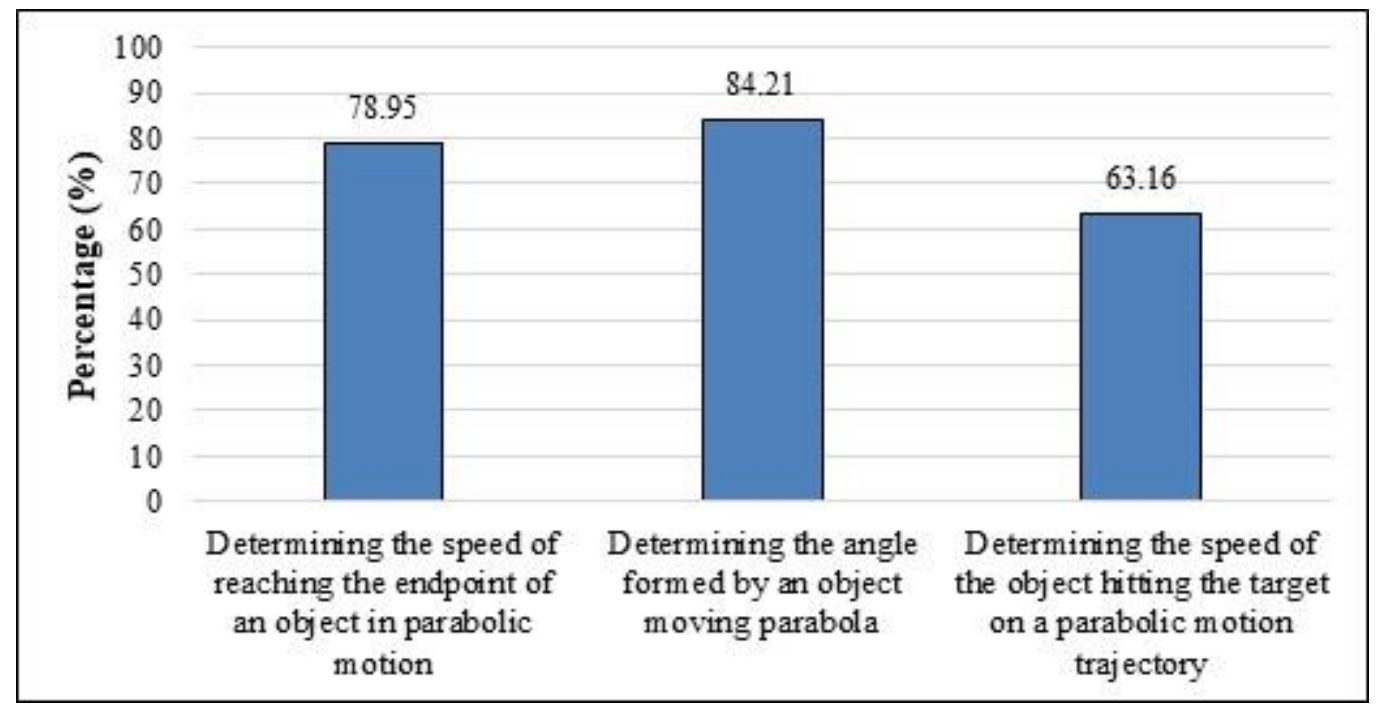

Figure 6. Learning Difficulty Profile Based on Structured Knowledge 
The diagnostic test indicators in this profile are: 1) Determining the speed of reaching the endpoint of an object in parabolic motion, 2) Determining the angle formed by an object moving parabola, and 3) Determining the speed of the object hitting the target on a parabolic motion trajectory. Based on the results of the data analysis shown in Figure 6, it shows that the level of student difficulty in determining the angle of an object that moves parabolic is very high, which is $84.21 \%$. While the high level of difficulty is an indicator of determining the speed of reaching the endpoint of an object on a parabolic motion, which is worth $78.95 \%$ and an indicator of determining the speed of an object hitting the target on a parabolic motion trajectory, which is $63.16 \%$. Structured knowledge is one of the causes of learning difficulties because it elevates students' learning chronological process in constructing the incorrect knowledge since the very beginning of learning stages (Bernard et al., 2019).

In structured knowledge, students generally have difficulty using equations and arithmetic operations or mathematical calculations. Previous research states that one of the causes of students' learning difficulties is arithmetic operations or mathematical calculations, and also other causes are understanding concepts and converting units (Duran \& Sendag, 2012). Furthermore, students also do not understand the equation of the farthest distance and the highest point of parabolic motion. In line with the research, learning physics has several problems, one of which is that students easily forget because the teaching system emphasizes understanding physics equations (Har, 2013). Students said that they had difficulty in solving problems, which should be like there were several stages in solving them, but it was difficult to understand the physical equations that had to be used. Students experience errors in answering questions by $54 \%$ because they only focus on understanding the equations of time taken during a half parabolic trajectory, maximum height, maximum farthest distance, and it is difficult to apply them in situations or trajectories (Karim \& Saepuzaman, 2016a).

\section{Factors Causing Learning Difficulties}

\section{Internal Factors}

Based on the results of interviews related to the factors causing learning difficulties, the researchers found that there were 8 internal factors that caused students to have learning difficulties, namely body defects, fatigue, attention, readiness, habits, how to receive lessons, and boredom. Thus, poor health conditions can interfere with learning activities. Based on the results of interviews from informants that the body defects they experience can interfere with or affect their learning process. In addition to the condition of the body that has a disability, a tired body condition can also interfere with the learning process. This is reinforced by the research of Sawawa et al. (2018). Someone who has an unhealthy body condition can make the body tired quickly, less enthusiastic, easily sleepy and feel dizzy, so that a person's health condition greatly influences learning outcomes (Li et al., 2018).

The researcher continued the interview by asking the question: "How can you receive a good lesson because of your disability?" especially for MS, the student who has limited visibility. The results of the interview stated that near-sightedness interfered with the learning process. The resource person did the solution by sitting next to the board.

The next internal factor is the psychological factor (intellective) in the aspect of attention. Based on the results of interviews, it was found that the lack of attention of students 
in learning will lead to a lack of effort in learning, so that students become less proficient or slow in solving problems in learning (Kallesta et al., 2018). Another psychological factor that influences the student's learning process is non-intellective psychological factors on the aspect of readiness (Simpson \& Willer, 2015). In this study, it was explained based on the results of interviews with respondents who stated that there were students who did not even have learning readiness at all. The reason for not having the readiness to learn is because they are lazy and have a lot of tasks to do. It can be concluded that the lack of learning readiness can affect the learning acceptance process (Rohayani, 2015).

The next aspect of non-intellective psychological factors is a habit. Based on the results of the interviews, the researchers found that there was not even a habit of reviewing the learning carried out by students. This is in line with research by Arief et al. (2012) that students do not have study habits or do not review lessons at home because students think that the subject matter is difficult to understand. Factors of physical and psychological maturity in the learning process of each individual are ready to receive and respond to lessons well. When students lose focus on learning, students will pay less attention to learning well. In line with it, students tend to do things they want and even don't pay attention to lessons because they have poor grasping power or the ability to accept lessons (Erna et al., 2021).

Another physical and psychological maturity factor is boredom which can also affect the learning process. This was explained by several respondents, namely that they had felt bored when studying physics for several reasons, namely because physics had many formulas, it was difficult to solve practice questions, the learning time was long, and there were even materials that students did not like. This boredom will reduce the concentration of student learning. In addition, it is reinforced by research by previous research. Students tend to feel bored because of a lack of interest in the teaching methods used by educators, and there is no explanation about the benefits of the material being studied (Turner \& Turner, 2018).

\section{External Factors}

Based on interviews, the researchers found that there were 5 factors that caused students to have learning difficulties, namely the lecturer's teaching methods, discipline, building conditions, community life forms, and weather conditions. The first factor is the lecturer's teaching method, in learning basic physics I was taught by two lecturers, one of the lecturers made the students less understand the material being explained, because they explained only through in focus and the formulas were not re-explained on the blackboard. Thus, the importance of lecturers paying attention to how to teach learning to students in order to understand the material being taught (Rahayu et al., 2020). As explained by related former research, students will not like the lesson or the teacher, even be lazy to learn because the teaching method used is not good (Chusni \& Hasanah, 2018).

Discipline is very important in the world of education, some respondents said that they had come late to campus, for reasons of getting up late, getting stuck in traffic, even the problem of the vehicle being used. The lack of student discipline in participating in learning is one of the factors causing learning difficulties (Alyusfitri \& Wahyuni, 2017). The state of the building for learning is also important for the continuity of the learning process. Based on the results of interviews, researchers found that the Physics Education Department did not have a fixed study room. The condition or location of the school building is bad, even the 
environment and learning facilities that are less supportive will interfere with learning concentration and will have an impact on learning achievement (Pitafi et al., 2012).

A less supportive community environment will hinder social, psychological development, and even academic achievement for students (Çelik et al., 2018). As the respondent said in the interview, in the neighborhood where they live there are people who play music loudly, people who are drunk like to shout, so that it disturbs students who are studying. Weather conditions that are not good or rainy, it can prevent students from going to campus because some use motorized vehicles, some are lazy to study, because the rainy weather makes students want to rest rather than study. One of the causes of learning difficulties is physical environmental factors such as unfavorable weather or climate conditions (Kang \& Doerr, 2012; Nahulae \& Zamtinah, 2020).

\section{Conclusions}

Students still have difficulty understanding the parabolic motion material. Based on the learning objectives and material profile, the overall assessment results from the diagnostic test that 19 students have not completed in achieving the learning objectives in understanding the sub-materials parabolic motion, because the highest score obtained by one of the students is 53, while the minimum completeness reaches a value of 56. The test indicators in the learning objectives approach have a percentage of $42.1 \%, 57.9 \%, 68.42 \%$. The test indicators on the material profile approach have percentages of $63.16 \%, 68.42 \%, 89.47 \%$. Based on the knowledge prerequisite approach, the percentage of each test indicator is $47.37 \%, 89.47 \%$, $89.47 \%$. Based on the misconception approach, the percentage of each test indicator is $26.32 \%, 78.95 \%, 94.74 \%$. Based on the structured knowledge approach the percentage of each test indicator is $63.16 \%, 78.95 \%, 84.21 \%$. These difficulties are influenced by internal factors, namely body defects, fatigue, attention, readiness, habits, how to receive lessons, boredom; and external factors, namely the lecturer's teaching methods, discipline, building conditions, forms of community life, and weather conditions.

\section{References}

Alyusfitri, R., \& Wahyuni, Y. (2017). Analisis Diagnostik Kesulitan Belajar Mahasiswa PGSD Pada Mata Kuliah Konsep Dasar Matematika II. Al-Jabar : Jurnal Pendidikan Matematika, 8(2), 145. https://doi.org/10.24042/ajpm.v8i2.1940

Arief, M. K., Handayani, L., \& Dwijananti, P. (2012). Identifikasi Kesulitan Belajar Fisika Pada Siswa RSBI: Studi Kasus Di RSMABI Se Kota Semarang. UPEJ Unnes Physics Education Journal, 1(2).

Bernard, M., Sunaryo, A., Tusdia, H., Hendriani, E., Suhayi, A., Nurhidayah, Parida, M., Fauzi, A., \& Rolina, R. (2019). Enhance Learning Independence and Self Ability of Exceptional Children Through Developing Learning Media VBA for Excel Games. Journal of Physics: Conference Series, 1315(1). https://doi.org/10.1088/17426596/1315/1/012037

Biben, S., Orkin, S., \& Bopp, C. (2016). Prevalence of Metabolic Syndrome Risk Factors in College-Aged Students. International Journal of Exercise Science: Conference Proceedings, 9(4), 20.

Binkley, M., Erstad, O., Herman, J., Raizen, S., Ripley, M., Miller-Ricci, M., \& Rumble, M. (2012). Defining twenty-first century skills. In Assessment and teaching of 21 st century skills (pp. 17-66). Springer. 
Briliana, V., \& Mursito, N. (2017). Exploring Antecedents and Consequences of Indonesian Muslim Youths' Attitude Towards Halal Cosmetic Products: A Case Study in Jakarta. Asia Pacific Management Review, 22(4), 176-184. https://doi.org/10.1016/j.apmrv.2017.07.012

Budiarti, I. S., \& Tanta, T. (2021). Analysis On Students' Scientific Literacy of Newton's Law and Motion System in Living Things. Jurnal Pendidikan Sains Indonesia (Indonesian Journal of Science Education), 9(1), 36-51.

Çakici, Y., \& Turkmen, N. (2013). An Investigation of the Effect of Project-Based Learning Approach on Children's Achievement and Attitude in Science. The Online Journal of Science and Technology, 3(2), 9-17.

Çelik, A., Yaman, H., Turan, S., Kara, A., Kara, F., Zhu, B., Qu, X., Tao, Y., Zhu, Z., Dhokia, V., Nassehi, A., Newman, S. T., Zheng, L., Neville, A., Gledhill, A., Johnston, D., Zhang, H., Xu, J. J., Wang, G., ... Dutta, D. (2018). No 主観的健康感を中心とし た在宅高齢者における 健康関連指標に関する共分散構造分析Title. In Journal of Materials Processing Technology (Vol. 1, Issue 1). http://dx.doi.org/10.1016/j.cirp.2016.06.001\%0Ahttp://dx.doi.org/10.1016/j.powtec.2016 .12.055\%0Ahttps://doi.org/10.1016/j.ijfatigue.2019.02.006\%0Ahttps://doi.org/10.1016/j. matlet.2019.04.024\%0Ahttps://doi.org/10.1016/j.matlet.2019.127252\%0Ahttp://dx.doi.o

Cheng, H.-M., \& Hoe, S.-Z. (2017). Students' Responses Under "Negative Pressure" to Respiratory Questions at the 15th Physiology Quiz International Event: 100 Medical School Teams from 22 Countries. BLDE University Journal of Health Sciences, 2(2), 105.

Cheng, S.-C., She, H.-C., \& Huang, L.-Y. (2017). The Impact of Problem-Solving Instruction on Middle School Students' Physical Science Learning: Interplays of Knowledge, Reasoning, and Problem Solving. Eurasia Journal of Mathematics, Science and Technology Education, 14(3), 731-743.

Chusni, M. M., \& Hasanah, A. (2018). Pengaruh Kemampuan Pengelolaan Laboratorium dan Literasi Sainfik Terhadap Kesiapan Calon Guru Fisika. Berkala Ilmiah Pendidikan Fisika, 6(3), 325. https://doi.org/10.20527/bipf.v6i3.5222

Darimi, I. (2016). Diagnosis Kesulitan Belajar Siswa dalam Pembelajaran Aktif di Sekolah. JURNAL EDUKASI: Jurnal Bimbingan Konseling, 2(1), 30-43.

Duran, M., \& Sendag, S. (2012). A Preliminary Investigation Into Critical Thinking Skills of Urban High School Students: Role of an IT/STEM Program. Creative Education, 3(02), 241.

Erna, M., Anwar, L., \& Mazidah, M. (2021). Interactive E-Module Using Zoom Cloud Meeting Platform to Reduce Misconceptions on Salt Hydrolysis Material. Journal of Education and Learning (EduLearn), 15(2), 283-290. https://doi.org/10.11591/edulearn.v15i2.18460

Gong, J. W., Liu, H. C., You, X. Y., \& Yin, L. (2021). An Integrated Multi-Criteria Decision Making Approach with Linguistic Hesitant Fuzzy Sets for E-Learning Website Evaluation and Selection. Applied Soft Computing, 102.

Griffin, P., Care, E., \& McGaw, B. (2012). The Changing Role of Education and Schools. In Assessment and teaching of 21st century skills (pp. 1-15). Springer.

Handhika, J., Purwandari, P., Cari, C., Suparmi, S., \& Sunarno, W. (2015). Profil Konsepsi Mahasiswa pada Materi Kinematika. Prosiding SNPS (Seminar Nasional Pendidikan Sains), 2, 167-172.

Har, E. (2013). Pengaruh Pembelajaran IPA Terhadap Keterampilan Teknologi Siswa Sekolah Menengah Atas di Sumatera Barat. Proceeding Biology Education Conference: Biology, Science, Enviromental, and Learning, 10(1).

Haris, V. (2016). Identifikasi Miskonsepsi Materi Mekanika dengan Menggunakan CRI 
(Certainty of Response Index). Ta'dib, 16(1).

Herga, N. R., Cagran, B., \& Dinevski, D. (2016). Virtual Laboratory in the Role of Dynamic Visualisation for Better Understanding of Chemistry in Primary School. Eurasia Journal of Mathematics, Science and Technology Education, 12(3), 593-608.

Hesse, F., Care, E., Buder, J., Sassenberg, K., \& Griffin, P. (2015). A Framework for Teachable Collaborative Problem Solving Skills. In Assessment and teaching of 21st century skills (pp. 37-56). Springer.

Islam Pitafi, A., Farooq Principal, M., \& Khadizai, G. (2012). Measurement of Scientific Attitude of Secondary School Students in Pakistan. Academic Rearch International, 2(2), 379-392. www.savap.org.pk\%5Cnwww.journals.savap.org.pk

Jamal, F. (2019). Analisis Kesulitan Belajar Siswa dalam Mata Pelajaran Matematika pada Materi Peluang Kelas XI IPA SMA Muhammadiyah Meulaboh Johan Pahlawan. MAJU: Jurnal Ilmiah Pendidikan Matematika, 1(1).

Junaidi, M. K. P., \& Lutfianto, M. (n.d.). Pengaruh Problem Based Learning Terhadap Hasil Belajar Siswa Pada Materi Trigonometri. Jurnal Pembelajaran Matematika, 5(2).

Kallesta, K. S., Yahya, F., \& Erfan, M. (2018). Analisis Faktor Penyebab Kesulitan Belajar IPA Fisika pada Materi Bunyi Kelas VIII SMP Negeri 1 Labuhan Badas Tahun Ajaran 2016/2017. Quark: Jurnal Inovasi Pembelajaran Fisika Dan Teknologi, 1(1), 51-57.

Kaltakci-Gurel, D., Eryilmaz, A., \& McDermott, L. C. (2017). Development and Application of a Four-Tier Test to Assess Pre-Service Physics Teachers' Misconceptions About Geometrical Optics. Research in Science and Technological Education, 35(2), 238-260. https://doi.org/10.1080/02635143.2017.1310094

Kang, K., \& Doerr, K. H. (2012). Case Study: Readiness and Total Ownership Cost Analyses for New Fighter Aircraft, F-XX. Naval Postgraduate School Monterey Ca Graduate School Of Business And Public ....

Kareth, Z. V., Dahlan, K., Akbar, M., \& Togibasa, O. (2018). Harmonic Oscillation Characteristic using Visual Basic Application. Journal of Physics: Conference Series, 1028(1), 0-5. https://doi.org/10.1088/1742-6596/1028/1/012046

Karim, S., \& Saepuzaman, D. (2016a). Analisis Kesulitan Mahasiswa Calon Guru Fisika Dalam Memahami Konsep Gerak Parabola. V, SNF2016-OER-51-SNF2016-OER-56. https://doi.org/10.21009/0305010409

Karim, S., \& Saepuzaman, D. (2016b). Analisis Kesulitan Mahasiswa Calon Guru Fisika dalam Memahami Konsep Gerak Parabola. Prosiding Seminar Nasional Fisika (EJournal), 5, SNF2016-OER.

Khandagale, V. S., \& Chavan, R. (2017). Identification of Misconceptions for Gravity, Motion and Inertia among Secondary School Students. Online Submission, 4(11), 197205.

Kurniawan, D. A., Perdana, R., \& Kurniasari, D. (2018). Identification of Student Attitudes Toward Physics Learning at Batanghari District High School (pp. 2(9), 475-484).

Kusumah, R. G. T. (2019). Peningkatan Kemampuan Berfikir Kritis Mahasiswa Tadris IPA Melalui Pendekatan Saintifik Pada Mata kuliah IPA Terpadu. IJIS Edu: Indonesian Journal of Integrated Science 71. https://doi.org/10.29300/ijisedu.v1i1.1762

Lee, M. C. (2016). Knowledge Management and Innovation Management: Best Practices in Knowledge Sharing and Knowledge Value Chain. International Journal of Innovation and Learning, 19(2), 206-226. https://doi.org/10.1504/IJIL.2016.074475

Lei, D., Ren, Y., \& Wang, Z. (2020). Numerical Study of Conduction and Radiation Heat Losses from Vacuum Annulus in Parabolic Trough Receivers. Frontiers in Energy, 112.

Li, J., Ye, H., Tang, Y., Zhou, Z., \& Hu, X. (2018). What Are the Effects of Self-Regulation 
Phases and Strategies for Chinese Students? A Meta-Analysis of Two Decades Research of the Association Between Self-Regulation and Academic Performance . In Frontiers in Psychology (Vol. 9, p. https://www.frontiersin.org/article/10.3389/fpsyg.2018.02434

Linh, N. Q., Duc, N. M., \& Yuenyong, C. (2019). Developing Critical Thinking of Students Through STEM Educational Orientation Program in Vietnam. Journal of Physics: Conference Series, 1340(1), 12025.

Ma'rifah, E. (2016). Identifikasi Kesulitan Siswa pada Materi Suhu dan Kalor. Jurnal Pembelajaran Fisika, 4(5), 124-133.

Milenković, D. D., Hrin, T. N., Segedinac, M. D., \& Horvat, S. (2016). Development of a Three-Tier Test as a Valid Diagnostic Tool for Identification of Misconceptions Related to Carbohydrates. Journal of Chemical Education, 93(9), 1514-1520. https://doi.org/10.1021/acs.jchemed.6b00261

Mukhopadhyay, D. R. (2014). Scientific Attitude - Some Psychometric Considerations. IOSR Journal of Humanities and Social Science, 19(1), 98-100. https://doi.org/10.9790/0837191798100

Nahulae, E. M., \& Zamtinah, Z. (2020). The Effect of Outdoor Learning Model on Improving Cognitive Ability in Entrepreneurial Learning At The Field Of Electricity. Journal of Education and Learning (EduLearn), 14(4), 473-480. https://doi.org/10.11591/edulearn.v14i4.16463

Ndihokubwayo, K., Uwamahoro, J., \& Ndayambaje, I. (2020). Effectiveness of PhET Simulations and YouTube Videos to Improve the Learning of Optics in Rwandan Secondary Schools. African Journal of Research in Mathematics, Science and Technology Education, 24(2), 253-265.

Ngang, T. K., Nair, S., \& Prachak, B. (2014). Developing Instruments to Measure Thinking Skills and Problem Solving Skills Among Malaysian Primary School Pupils. ProcediaSocial and Behavioral Sciences, 116, 3760-3764.

Nisa, F., Yuliati, L., \& Mufti, N. (2019). Miskonsepsi Konsep Gerak Satu dan Dua Dimensi Siswa SMA. 1380-1385.

Nofitasari, I., \& Sihombing, Y. (2017). Deskripsi Kesulitan Belajar Peserta Didik dan Faktor Penyebabnya dalam Memahami Materi Listrik Dinamis Kelas X SMA Negeri 2 Bengkayang. Jurnal Penelitian Fisika Dan Aplikasinya (JPFA), 7(1), 44-53.

Nugraheni, D. (2017). Analisis Kesulitan Belajar Mahasiswa pada Mata Kuliah Mekanika. Edu Sains: Jurnal Pendidikan Sains Dan Matematika, 5(1), 23-32.

Pertiwi, D. (2012). Jurnal pembelajaran fisika. 1(September), 77-85.

Rahayu, G. D. S., Bernard, M., Mulyono, D., \& Rabbani, S. (2020). VBA Media Development for Microsoft Excel Against Students' Mathematical Problem Solving. Journal of Physics: Conference Series, 1657(1). https://doi.org/10.1088/17426596/1657/1/012079

Rodriguez-Gil, L., Garcia-Zubia, J., Orduña, P., \& Lopez-de-Ipina, D. (2016). Towards New Multiplatform Hybrid Online Laboratory Models. IEEE Transactions on Learning Technologies, 10(3), 318-330.

Rohayani, A. H. H. (2015). A Literature Review: Readiness Factors to Measuring E-Learning Readiness in Higher Education. Procedia Computer Science, 59, 230-234.

Rosdianto, H. (2019). Students' Science Process Skills Through Generative Learning Model In the Topic of Light. JIPF (Jurnal Ilmu Pendidikan Fisika), 4(1), 8. https://doi.org/10.26737/jipf.v4i1.792

Rusilowati, A. (2006). Profil Kesulitan Belajar Fisika Pokok Bahasan Kelistrikan Siswa SMA di Kota Semarang. Jurnal Pendidikan Fisika Indonesia, 4(2).

Rusilowati, A. (2015). Pengembangan Tes Diagnostik sebagai Alat Evaluasi Kesulitan 
Belajar Fisika. Prosiding: Seminar Nasional Fisika Dan Pendidikan Fisika, 6(1).

Salis, C., Wilson, M. F., Murgia, F., Monni, S. L., Brunetti, G., Mameli, A., \& Atzori, F. (2016). First Monitoring Results of the "Tutti a Iscol@” Project-A Technology Based Intervention to Keep Difficult-to-Motivate Pupils in the School Mainstream System. ELearn: World Conference on E-Learning in Corporate, Government, Healthcare, and Higher Education, 882-887.

Saripudin, A. (2018). Praktis Belajar Fisika Untuk Kelas X. Edusoftware.

Sarojo, G. A. (2002). Seri Fisika Dasar Mekanika. Jakarta: Salemba Teknika.

Sawawa, D., Solehudin, A., \& Sabri, S. (2018). Pengaruh Faktor Internal dan Eksternal Siswa Terhadap Hasil Belajar pada Mata Pelajaran Mekanika Teknik dan Elemen Mesin. Journal of Mechanical Engineering Education, 5(1), 21-26.

Serway, R. A., \& Jewett, J. W. (1998). Principles of Physics (Vol. 1). Saunders College Pub. Fort Worth, TX.

Setyono, A., Nugroho, S. E., \& Yulianti, I. (2016). Analisis Kesulitan Siswa dalam Memecahkan Masalah Fisika Berbentuk Grafik. UPEJ Unnes Physics Education Journal, 5(3), 32-39.

Setyono, D. A., Cahyono, D. D., \& Helmy, M. (2016). Measuring Service Capacity of Public Facilities Based on Supply Aspect (Case Study: Elementary School in Malang City). Procedia-Social and Behavioral Sciences, 227, 45-51.

Silva, M., \& Almeida, A. (2017). Primary School Pupils' Misconceptions of the Human Respiratory System in Primary School Students: From Identification To Deconstruction. 10th Annual International Conference of Education, Research and Innovation, 1.

Simpson, B., \& Willer, R. (2015). Beyond Altruism: Sociological Foundations of Cooperation and Prosocial Behavior. Annual Review of Sociology, 41(1), 43-63. https://doi.org/10.1146/annurev-soc-073014-112242

Sudijono, A. (2010). Pengantar Statistik Pendidikan. Jakarta: Rajawal Press.

Sugiyono, P. D. (2013). Metode Penelitian Manajemen. Bandung: CV Alfabeta.

Theasy, Y., Wiyanto, W., \& Sujarwata, S. (2017). Identifikasi Kesulitan Belajar Fisika Berdasarkan Kemampuan Multi Representasi. Physics Communication, 1(2), 1-5.

Trisniarti, M. D., Aminah, N. S., \& Sarwanto, S. (2020). Profile of Senior High School Students' Misconception in Physics Using Need-Based Analysis. Journal of Physics: Conference Series, 1567(3). https://doi.org/10.1088/1742-6596/1567/3/032072

Turner, A., \& Turner, A. (2018). Generation Z: Technology and Social Interest Generation $Z$ : Technology and Social Interest. 71(2), 103-113.

Volfson, A., Eshach, H., \& Ben-Abu, Y. (2020). Identifying Physics Misconceptions at the Circus: The Case of Circular Motion. Physical Review Physics Education Research, 16(1), 10134.

Wardani, U. A. (2016). Pengembangan Model Pembelajaran Discovery Learning dengan Data Sharing Technology pada Pokok Bahasan Energi. Jurnal Riset Dan Kajian Pendidikan Fisika, 3(1), 23-25.

Wijayanti, A. (2016). Implementasi Model Pembelajaran Kooperatif Tipe TGT sebagai Upaya Meningkatkan Pemahaman Konsep Fisika Dasar Mahasiswa Pendidikan IPA. Jurnal Pijar Mipa, 11(1).

Winarti, C., Cari, A., Suparmi, I., Budiarti, J., Handhika, H., \& Viyanti, V. (2017). Identification of Consistency and Conceptual Understanding of the Black Principle. Ideas for 21st Century Education, 2004, 249-252. https://doi.org/10.1201/9781315166575-50

Yolanda, Y. (2017). Remediasi Miskonsepsi Kinematika Gerak Lurus dengan Pendekatan STAD. SPEJ (Science and Physic Education Journal), 1(1), 39-48.

Zatsiorsky, V. M., \& Zaciorskij, V. M. (2002). Kinetics of Human Motion. Human Kinetics. 